\title{
EFFECT OF DIFFERENT FERTILIZERS AND AMENDMENTS ON THE GROWTH OF APPLE AND SOUR CHERRY ROOTSTOCKS IN AN ORGANIC NURSERY
}

\author{
Zygmunt S. Grzyb, Wojciech Piotrowski, Paweł Bielicki, \\ Lidia Sas Paszt and Eligio Malusà
}

Research Institute of Horticulture, Department of Pomology

Pomologiczna 18, 96-100 Skierniewice, POLAND

e-mail: zgrzyb@insad.pl

(Received February 20, 2012/Accepted April 25, 2012)

\section{A B S T R A C T}

Two independent trials were established during the years of 2009 and 2010 with M.26 apple rootstocks and Prunus mahaleb L. seedlings in three different locations to evaluate the effect of seven organic fertilizers and amendments on the growth of rootstocks in an organic nursery in the first year of an operation. The products tested were a microbial consortium, two kinds of vermicomposts extracts, two kind of seaweeds extracts, a stillage from yeast production and a solution of titanium. Plants receiving these products were compared to untreated and minerally or organically (manure) fertilized during vegetative season. Plant growth was evaluated by measuring the increase of the root neck diameter and the height of the tallest upward growing shoot. The application of the different organic fertilizers and amendments induced significantly higher growth of both kinds of rootstocks in all locations and for each year in comparison to control and, in the majority of the cases, to the chemical and manure fertilization. However, some products (BF Quality, Micosat, Humus UP, Tytanit and Vinassa) showed a more consistent effect on the growth of tested rootstocks under different soil and climatic conditions. It can be concluded that fertilization of apple and sour cherry rootstock with organic fertilizers and amendments of different origin and composition is effective in producing of high quality plants.

Key words: M.26 apple, Prunus mahaleb cherry rootstocks, bioproducts application, organic nursery 


\section{INTRODUCTION}

In most nurseries, fruit trees are usually produced after a two-year cycle (Rejman and Makosz, 1994; Słowiński, 2001). In the first year, rootstocks are planted and in the summer, the selected cultivars are budded onto them; during the second year the maiden trees are properly maintained and fertilized to assure a final high quality of the plants (Kłossowski and Czynczyk, 1974; Janisz et al., 2000; Wójcik, 2009).

However, the quality of the rootstock plant determines the percentage of successful grafted buds. Then they can withstand the period of winter dormancy without significant losses, and the number and quality of maiden trees that will be grown out of them in the second year of the production cycle (Rejman and Makosz, 1994; Słowiński and Sadowski, 2000; Gudarowska and Szewczuk, 2004).

To ensure optimal growing conditions for rootstocks in conventional nurseries, different mineral fertilizers are used (Wójcik, 2009). In organic nurseries to stimulate plant growth, farmers are able use only the fertilizers and soil conditioners allowed by the EU Regulation nr 889/2008 laying down detailed rules for organic production (Ciesielska et al., 2011). Among them humic extracts or amino acids of plant origin, and extracts from marine algae are listed. There were shown efficient in trials with fruit trees (Malusà et al., 2004; Grzyb et al., 2012).

The aim of this study was to evaluate the effect of different organic fertilizers and amendments on the growth of apple and cherry rootstocks after biopreparations have been applied to their leaves and the soil in organic nursery in the first year of operation.

\section{MATERIAL AND METHODS}

Two independent trials were established during the years of 2009 and 2010 with M.26 apple rootstocks and Prunus mahaleb seedlings. In 2009, two experimental plots were set in the locations named Maków (B) and Mokra Lewa (C). In the second season (2010) was added in Dąbrowice (A).

The three locations differed for the soil texture, but nutrient content was quite similar. Soil $\mathrm{pH}$ ranged between 5.0-5.5. Soil mineral nutrient content was in the following range: $0.07-0.1 \%$ $\mathrm{N}$; 6.7-7.4 mg P-100 g soil; 3.1-3.9 mg $\mathrm{K} \cdot 100 \mathrm{~g}$ soil; 3.4-3.7 mg Mg.100 g soil. In Dąbrowice, in the year preceding the experiment (2009), mustard and other ground cover plants were grown on the plot and incorporated into the soil at blooming, to serve as organic fertilization and to reduce the occurrence of soil-borne pathogens. In Mokra Lewa a phacelia and vetch mixture was grown for the similar reason, while in Maków the plot was cultivated with cereals.

The experiment was set up in a randomized block design with four replications and ten rootstocks were planted on each plots. In both years of investigation the following fertilization treatments were applied to the plots:

1 No treatment (Control).

2 Mineral (NPK) fertilization: at a dose of $176.4 \mathrm{~kg} \cdot \mathrm{ha}^{-1} \mathrm{NH}_{4} \mathrm{NO}_{3}$, 
$65.2 \mathrm{~kg} \cdot \mathrm{ha}^{-1}$ triple super phosphate, and $160 \mathrm{~kg} \cdot \mathrm{ha}^{-1} \mathrm{~K}_{2} \mathrm{SO}_{4}$, (NPK).

3 Granulated manure (Fertigo, FermO-Feed, the Netherland) at a dose of $1500 \mathrm{~kg} \cdot \mathrm{ha}^{-1}$, (Manure).

4 Microbial inoculum formed of mycorrhizal fungi (Glomus mosseae and $G$. intraradices), and plant growth promoting bacteria (Pseudomonas fluorescence and Bacillus subtilis strains) (Micosat, CCS Aosta Srl, Italy): a granular formulation (Micosat F12 WP) was applied at planting to the soil at a dose of $100 \mathrm{~kg} \cdot \mathrm{ha}^{-1}$, and a second application was carried out in mid-June in liquid form (Micosat F MS 200) at a dose of $10 \mathrm{~kg} \cdot \mathrm{ha}^{-1}$, (Micosat).

5 Extract from vermicompost (Humus UP, Przedsiębiorstwo Produkcyjno-Handlowe Ekodarpol, Poland) applied to the soil as a $2 \%$ solution at a dose of $20 \mathrm{l} \cdot \mathrm{ha}^{-1}$, (Humus UP).

6 Extract from vermicompost and additionally a product derived from molasses (Humus Active + Aktywit PM, Przedsiębiorstwo Produkcyjno-Handlowe Ekodarpol, Poland). Humus Active was applied to the soil as $2 \%$ solution at a dose of $201 \cdot$ ha $^{-1}$ and Aktywit PM applied to the soil as a $1 \%$ solution at a dose of $101 \cdot$ ha $^{-1}$, (Humus Active).

7 Seaweed extract reinforced with aminoacids (BioFeed Amin, Agrobio Products B.V., the Netherland), applied to leaves as a $0.5 \%$ solution at a dose of $51 \cdot \mathrm{ha}^{-1}$, (BF Amin).

8 Seaweed extract reinforced with humic and fulvic acids (BioFeed Quality, Agrobio Products B.V., the
Netherland), applied to leaves as a $0.5 \%$ solution, at a dose of $51 \cdot \mathrm{ha}^{-1}$, (BF Quality).

9 Titanium (Tytanit, Intermag, Poland) applied to leaves as a $0.05 \%$ solution. at a dose of $0.51 \cdot \mathrm{ha}^{-1}$, (Tytanit).

10 Stillage from the production of yeasts (Mazowiecka Fabryka Drożdży "Józefów" Sp. z o.o., Poland), applied to leaves as a $0.5 \%$ solution, at a dose of $51 \cdot h^{-1}$ (Vinassa).

The plants treated with Micosat, BF Amin, BF Quality, Tytanit and Vinassa received before planting a soil fertilization with half dose of granulated manure $\left(75 \mathrm{~g} \cdot \mathrm{m}^{-2}\right)$.

All organic fertilizers (except the dry manure) were applied twice: the first time at planting (mid-May) and the second time in mid-June. Following each application, the soil around the plants was thoroughly mixed by hands with hoes.

Plant growth was evaluated by measuring the increase of the trunk diameter (at a height of $5 \mathrm{~cm}$ above ground) and the height of the tallest upward growing shoots. In the autumn (mid-October), after measuring obtained data were elaborated statistically using a one-way analysis of variance for a randomized block design. Multiple comparisons of means for the combinations were performed with Tukey's test at a significance level of $p=0.05$. In the tables, the data in the column that do not differ significantly from one another are marked with the same letters. 
Z.S. Grzyb et al.

RESULTS

The application of the different organic fertilizers and amendments to apple and sour cherry rootstocks induced significantly the growth to both kinds of rootstocks in all locations and for each year. In 2009, presentation of data collected in Dąbrowice was abandoned, because of considerable soil-related variability. The data obtained in 2010, concerning the increase in the thickness and height of the rootstocks, gathered from all three nurseries (also called sites), are summarized in Tables 1 and 2.

Table 1. Growth intensity of M.26 apple rootstocks treated with different bioproducts in nurseries at Dąbrowice (A), Maków (B) and Mokra Lewa (C) in 2009-2010

\begin{tabular}{|c|c|c|c|c|c|}
\hline \multirow{3}{*}{ Treatment } & \multicolumn{5}{|c|}{ Increase in thickness of rootstocks [mm] } \\
\hline & \multicolumn{2}{|c|}{2009} & \multicolumn{3}{|c|}{2010} \\
\hline & $\mathrm{B}$ & $\mathrm{C}$ & A & $\mathrm{B}$ & $\mathrm{C}$ \\
\hline No treatment (Control) & $4.8 \mathrm{a}^{*}$ & $1.8 \mathrm{a}$ & $1.9 \mathrm{a}$ & $3.1 \mathrm{a}$ & $3.5 \mathrm{a}$ \\
\hline NPK & $6.7 \mathrm{~b}$ & $2.8 \mathrm{bc}$ & $2.9 \mathrm{bc}$ & $3.6 \mathrm{ab}$ & $4.4 \mathrm{ab}$ \\
\hline Manure & $5.9 \mathrm{ab}$ & $2.8 \mathrm{bc}$ & $2.7 \mathrm{a}-\mathrm{c}$ & $4.3 \mathrm{bc}$ & $4.5 \mathrm{~b}$ \\
\hline Micosat & $6.6 \mathrm{~b}$ & $3.2 \mathrm{~b}-\mathrm{d}$ & $3.3 \mathrm{~b}-\mathrm{d}$ & $5.1 \mathrm{de}$ & $6.4 \mathrm{~cd}$ \\
\hline Humus UP & $6.3 \mathrm{~b}$ & $2.4 \mathrm{ab}$ & $2.9 \mathrm{bc}$ & $5.1 \mathrm{de}$ & $6.9 \mathrm{~d}$ \\
\hline Humus Active + Aktywit PM & $6.4 \mathrm{~b}$ & $3.0 \mathrm{bc}$ & $3.3 \mathrm{~b}-\mathrm{d}$ & $4.7 \mathrm{~cd}$ & $5.9 \mathrm{c}$ \\
\hline BF Amin & $5.8 \mathrm{ab}$ & $4.0 \mathrm{~d}$ & $3.7 \mathrm{~cd}$ & $3.7 \mathrm{ab}$ & $5.8 \mathrm{c}$ \\
\hline BF Quality & $5.5 \mathrm{ab}$ & $3.5 \mathrm{~cd}$ & $2.6 \mathrm{ab}$ & $4.2 \mathrm{bc}$ & $6.3 \mathrm{~cd}$ \\
\hline Tytanit & $6.3 \mathrm{~b}$ & $3.3 \mathrm{~b}-\mathrm{d}$ & $3.4 \mathrm{~b}-\mathrm{d}$ & $4.7 \mathrm{~cd}$ & $6.0 \mathrm{~cd}$ \\
\hline Vinassa & $6.8 \mathrm{~b}$ & $3.1 \mathrm{bc}$ & $3.9 \mathrm{~d}$ & $4.8 \mathrm{~cd}$ & $6.3 \mathrm{~cd}$ \\
\hline \multicolumn{6}{|c|}{ Height of rootstocks $[\mathrm{cm}]$} \\
\hline No treatment (Control) & $84.2 \mathrm{a}^{*}$ & $51.6 \mathrm{a}$ & $68.0 \mathrm{a}$ & $66.2 \mathrm{a}$ & $72.8 \mathrm{a}$ \\
\hline NPK & $96.5 \mathrm{c}$ & $59.7 \mathrm{a}-\mathrm{c}$ & $73.9 \mathrm{a}$ & $73.2 \mathrm{ab}$ & $78.8 \mathrm{ab}$ \\
\hline Manure & $93.8 \mathrm{bc}$ & $61.0 \mathrm{~b}-\mathrm{d}$ & $74.2 \mathrm{a}$ & $70.8 \mathrm{ab}$ & $82.5 \mathrm{~b}-\mathrm{d}$ \\
\hline Micosat & $92.6 \mathrm{a}-\mathrm{c}$ & $60.9 \mathrm{~b}-\mathrm{d}$ & $79.2 \mathrm{a}$ & $74.6 \mathrm{a}-\mathrm{c}$ & $86.6 \mathrm{c}-\mathrm{e}$ \\
\hline Humus UP & $96.8 \mathrm{c}$ & $56.3 \mathrm{ab}$ & $75.4 \mathrm{a}$ & $75.4 \mathrm{~b}-\mathrm{d}$ & $85.7 \mathrm{~b}-\mathrm{e}$ \\
\hline Humus Active + Aktywit PM & $98.3 \mathrm{c}$ & 58.6 a-c & $78.9 \mathrm{a}$ & $71.5 \mathrm{ab}$ & $86.7 \mathrm{c}-\mathrm{e}$ \\
\hline BF Amin & $89.2 \mathrm{a}-\mathrm{c}$ & $68.5 \mathrm{~d}$ & $80.5 \mathrm{a}$ & $76.5 \mathrm{~b}-\mathrm{e}$ & $86.6 \mathrm{c}-\mathrm{e}$ \\
\hline BF Quality & $85.2 \mathrm{ab}$ & $64.3 \mathrm{~b}-\mathrm{d}$ & $70.9 \mathrm{a}$ & $72.5 \mathrm{ab}$ & $82.2 \mathrm{~b}-\mathrm{d}$ \\
\hline Tytanit & $94.7 \mathrm{c}$ & $65.0 \mathrm{~cd}$ & $75.9 \mathrm{a}$ & $83.8 \mathrm{c}-\mathrm{e}$ & $90.6 \mathrm{e}$ \\
\hline Vinassa & $96.9 \mathrm{c}$ & $64.5 b-d$ & $80.5 \mathrm{a}$ & $84.9 \mathrm{e}$ & $89.1 \mathrm{de}$ \\
\hline
\end{tabular}

* Means in column followed by the same letter an each nursery localization are not significantly different at $\mathrm{p}=0.05$ 
Effect of different fertilizers and amendments...

Table 2. Growth intensity of $P$. mahaleb seedlings treated with different bioproducts in nurseries at Dąbrowice (A), Maków (B) and Mokra Lewa (C)

\begin{tabular}{|c|c|c|c|c|c|}
\hline \multirow{3}{*}{ Treatment } & \multicolumn{5}{|c|}{ Increase in thickness of rootstocks [mm] } \\
\hline & \multicolumn{2}{|c|}{2009} & \multicolumn{3}{|c|}{2010} \\
\hline & $\mathrm{B}$ & $\mathrm{C}$ & A & $\mathrm{B}$ & $\mathrm{C}$ \\
\hline No treatment (Control) & $7.5 \mathrm{a}^{*}$ & $5.3 \mathrm{a}$ & $4.4 \mathrm{a}$ & $2.5 \mathrm{a}$ & $2.9 \mathrm{a}$ \\
\hline NPK & $8.8 \mathrm{a}-\mathrm{c}$ & $6.9 \mathrm{~b}$ & $4.8 \mathrm{ab}$ & $3.7 \mathrm{bc}$ & $3.9 \mathrm{a}-\mathrm{c}$ \\
\hline Manure & $8.9 \mathrm{a}-\mathrm{c}$ & $8.6 \mathrm{~cd}$ & $5.4 \mathrm{a}-\mathrm{c}$ & $3.5 \mathrm{a}-\mathrm{c}$ & $4.5 \mathrm{c}$ \\
\hline Micosat & $8.5 \mathrm{ab}$ & $9.5 \mathrm{~cd}$ & $6.0 \mathrm{~b}-\mathrm{d}$ & $3.5 \mathrm{a}-\mathrm{c}$ & $4.4 \mathrm{c}$ \\
\hline Humus UP & $9.6 \mathrm{bc}$ & $9.2 \mathrm{~cd}$ & $5.9 \mathrm{~b}-\mathrm{d}$ & $4.8 \mathrm{~d}$ & $5.7 \mathrm{de}$ \\
\hline Humus Active + Aktywit PM & $8.9 \mathrm{a}-\mathrm{c}$ & $8.2 \mathrm{bc}$ & $5.1 \mathrm{ab}$ & $3.9 \mathrm{~b}-\mathrm{d}$ & $4.7 \mathrm{~cd}$ \\
\hline BF Amin & $9.6 \mathrm{bc}$ & $9.6 \mathrm{~d}$ & $6.8 \mathrm{de}$ & $4.1 \mathrm{~cd}$ & $4.3 \mathrm{bc}$ \\
\hline BF Quality & $10.5 \mathrm{c}$ & $8.6 \mathrm{~cd}$ & $6.9 \mathrm{de}$ & $5.0 \mathrm{~d}$ & $5.9 \mathrm{e}$ \\
\hline Tytanit & $9.5 \mathrm{bc}$ & $8.5 \mathrm{~cd}$ & $6.7 \mathrm{c}-\mathrm{e}$ & $2.9 \mathrm{ab}$ & $7.5 \mathrm{f}$ \\
\hline Vinassa & $9.2 \mathrm{a}-\mathrm{c}$ & $9.4 \mathrm{~cd}$ & $8.0 \mathrm{e}$ & $3.6 \mathrm{a}-\mathrm{c}$ & $5.8 \mathrm{e}$ \\
\hline \multicolumn{6}{|c|}{ Height of rootstocks $[\mathrm{cm}]$} \\
\hline No treatment (Control) & $94.1 \mathrm{a}^{*}$ & $94.2 \mathrm{a}$ & $81.2 \mathrm{a}$ & $70.9 \mathrm{a}$ & $77.6 \mathrm{a}$ \\
\hline NPK & $107.0 \mathrm{~b}$ & $110.4 \mathrm{~b}$ & $87.6 \mathrm{ab}$ & $84.5 \mathrm{~b}$ & $77.9 \mathrm{a}$ \\
\hline Manure & $105.2 \mathrm{~b}$ & $121.1 \mathrm{bc}$ & $96.7 \mathrm{~b}-\mathrm{d}$ & $89.9 \mathrm{bc}$ & $91.6 \mathrm{bc}$ \\
\hline Micosat & $107.4 \mathrm{~b}$ & $124.3 \mathrm{c}$ & $95.9 \mathrm{bc}$ & $93.6 \mathrm{~b}-\mathrm{d}$ & $82.5 \mathrm{ab}$ \\
\hline Humus UP & $113.5 \mathrm{~b}$ & $125.7 \mathrm{c}$ & $97.6 \mathrm{~b}-\mathrm{d}$ & $105.9 \mathrm{e}$ & $94.1 \mathrm{~cd}$ \\
\hline Humus Active + Aktywit PM & $107.2 \mathrm{~b}$ & $124.1 \mathrm{c}$ & $92.0 \mathrm{ab}$ & $100.1 \mathrm{c}-\mathrm{e}$ & $84.0 \mathrm{ab}$ \\
\hline BF Amin & $104.4 \mathrm{ab}$ & $130.0 \mathrm{c}$ & $109.7 \mathrm{de}$ & $89.0 \mathrm{bc}$ & $78.4 \mathrm{a}$ \\
\hline BF Quality & $110.7 \mathrm{~b}$ & $122.0 \mathrm{bc}$ & $113.4 \mathrm{e}$ & $102.5 \mathrm{de}$ & $94.8 \mathrm{~cd}$ \\
\hline Tytanit & $108.0 \mathrm{~b}$ & $122.9 \mathrm{c}$ & $106.0 \mathrm{c}-\mathrm{e}$ & $96.4 \mathrm{c}-\mathrm{e}$ & $103.4 \mathrm{~d}$ \\
\hline Vinassa & $110.9 \mathrm{~b}$ & $126.6 \mathrm{c}$ & $107.4 \mathrm{c}-\mathrm{e}$ & $95.0 \mathrm{~b}-\mathrm{e}$ & $96.5 \mathrm{~cd}$ \\
\hline
\end{tabular}

*Explanation: see Table 1

The M.26 apple rootstocks that were not fertilized at all showed the smallest increase in trunk thickness in all the nurseries. Mineral (NPK) fertilization applied in the first year of the study increased significantly the size of this increase relative to the control combination. However in the following year (2010) only in one of the three nurseries a significant beneficial effect of mineral fertilization on the thickness of the rootstocks was observed.

The bovine Manure (Fertigo) increased significantly the thickness of apple rootstocks in 2009 in only one 
of the nurseries, but in 2010 already in two out of the three of them. Micosat, like the biopreparations $\mathrm{Hu}-$ mus Active and Aktywit PM used together, stimulated clearly the increase in the thickness of the rootstocks in each of the three nurseries in both years of the study. In the first year of the study Humus UP increased significantly the thickness of the rootstocks in only one nursery, but the following year it did well already in all three locations. The preparations BF Amin and BF Quality in affected advantageously the growth of the rootstocks in thickness in only three out of the total of five year-site combinations, whereas Tytanit and Vinassa did so in all the nurseries in both years of the study.

When the effects of the tested bioproducts on the height of M.26 apple rootstocks are compared, it turns out that in all three nurseries in both years of the study these effects were the smallest comparison to the control. NPK fertilization significantly stimulated the growth of the rootstocks in height only in one of these nurseries in the two years of the study. Fertilization with the ecological manure Fertigo improved considerably plant growth in three out of the total number of five yearsite combinations. A beneficial effect of Micosat, like those of the preparation Humus UP and the combined use of the preparations Humus Active and Aktywit PM, and also of BF Quality, was evident in only two out of the five year-site combinations. A similar effect was observed following the use of the preparation BF
Amin on the rootstocks. The products Tytanit and Vinassa stimulated clearly the growth of M.26 apple rootstocks in height of shoots.

Prunus mahaleb seedlings as rootstocks for sour cherry trees with a zero dose of fertilizer were found to have the smallest root neck diameter in all three nurseries in both years of the study. The rootstocks fertilized with NPK, like those fertilized only with the ecological manure Fertigo, in two out of the five cases under assessment grew significantly in thickness more strongly than the control. On the other hand, Micosat and the vermicomposts extracts (Humus Active and Aktywit PM) used together were effective in stimulating growth in the thickness of the rootstocks only in three out of the five year-site combinations. $\mathrm{Hu}-$ mus UP increased significantly the thickness of the rootstocks in all the tested sites regardless of the year and location of the experiment. The products BF Amin, BF Quality and Tytanit had a very beneficial effect on the increase root neck diameter of P. mahaleb rootstocks. Vinassa significantly stimulated their growth in thickness in only three out of the five cases.

With regard to the effect of the tested bioproducts on the increase in height of $P$. mahaleb seedlings, it should be stated that the growth increments were the smallest in the control combination growing without any fertilization. In the combination with NPK fertilization a significant increase in height was found in only three out of the five year-site combi- 
nations. Granulated Manure (Fertigo), Micosat and Humus UP were found effective in stimulating the growth of $P$. mahaleb seedlings in height in all the cases, while Humus Active in combination with Aktywit PM, and also BF Amin, stimulated significantly the growth of the rootstocks in height in only two nurseries out of the total of five combinations under evaluation.

BF Quality was one of the few products that stimulated very clearly the growth of the rootstocks in height of shoots. Similar results were obtained following the use of the products Tytanit and Vinassa.

\section{DISCUSSION}

It was proved that the quality of rootstocks planted in the nursery often determines the quality of the maiden trees produced (Rejman and Makosz, 1994; Słowiński and Sadowski, 2000; Gudarowska and Szewczuk, 2004). It is paid much attention to the thickness of the rootstocks and the dynamics of their growth during the vegetation period, which determines whether the cambial tissue is sufficiently active during bud-grafting and whether the buds of the fruit tree cultivars grafted on the rootstocks in summer will take well and be ready for winter dormancy (Gudarowska and Szewczuk, 2004). Indeed, poorly growing rootstocks, which finish too early the intensive growth during the season due to limited nutrition, show weak grafted buds, thus reducing the effectiveness of trees production, as measured by the number of trees obtained per hectare.

The plants treated with the organic fertilizers received a significantly lower amount of nutrients than those fertilized with the standard NPK treatment. However, for both the tested rootstocks, in the different locations and years of the trials, a consistent similar or better result in comparison to the NPK treatment, in terms of plant growth, was measured. Such result could be due to different reasons deriving from the other mechanism of action that the products utilized might produce to the plant. Products such as Vinassa, BF Quality and BF Amin contain a nitrogen in the form of oligopeptides and amino acids. The availability of such forms could reduce the need of energy necessary to sustain uptake and transform inorganic forms of nitrogen (Khan et al., 2009), thus resulting in a more efficient use of the photosynthates for growth purposes. The vermicomposts extracts (Humus UP and Humus Active) contain a high amount of humus-like compounds which are considered to increase the general soil fertility, mainly through an increase of the microbiological population at the rhizosphere level (Piccolo et al., 1992; Van Trump et al., 2006) and a physiological effect on plants (Nardi et al., 2002). The microbial consortium (Micosat) showed to increase the rhizospheric population of mycorrhizal fungi and PGPR bacteria, thus increasing the availability of mineral nutrients through the enhanced capacity of nutrient uptake 
(Comerford, 2005; Sas Paszt et al., 2011; Bardi and Malusà, 2012). Titanium is considered to enhance the photosynthesis efficiency thus improving the growth performance of the plants (Wójcik, 2000). Therefore, it is not possible to univocally explain the effect of these products on the plant growth, but it is worth noting that with these products, even the application of a low dose of mineral nutrients can be sufficient to obtain a good growth of rootstock plants. Their overall efficacy shown by our trials is thus confirming results of earlier reports for products containing humic acids, plant amino acids and beneficial microorganisms in the nursery production of apple and sour cherry trees (Janisz et al., 2000; Smoleń, 2008, Khan et al., 2009).

In conventional nurseries, fertilizers containing nitrogen are generally applied to stimulate the growth of rootstocks (Kłosowski and Czynczyk, 1974; Marchers, 1995; Wójcik, 2005, 2009). In organic nurseries, however, such a possibility does not exist (Ciesielska et al., 2011). The results of the authors own studies that involved the testing of various organic products containing humic acids, plant amino acids and beneficial microorganisms, which are successfully used in organic farming of other plants, proved also satisfactory in the nursery production of apple and sour cherry trees (Van Trump et al., 2006; Janisz et al., 2000; Smoleń, 2008; Grzyb et al., 2012).

The attempts to use biopreparations to stimulate plant growth in the first year of running the nursery of apple and sour cherry rootstocks have shown that in order to get good, actively growing rootstocks it is necessary to supply the plants with adequate nutrients and beneficial microorganisms during their vegetation period. Each of the biopreparations tested in this experiment intensified the growth of rootstocks, but the best results in the case of both types of rootstocks were obtained following the use of the preparations Tytanit and Vinassa. The results are consistent with those obtained by using these products to stimulate growth intensity in other plant species (Wójcik, 2000; Malusà et al., 2007).

It is worth emphasizing that mineral fertilization of rootstocks appears not to be a better practice than the fertilization with organic products, an observation which is rarely mentioned (Grzyb et al., 2012). The reasons for this phenomenon are different: an important role in this process is probably played by soil microorganisms, which can be disturbed by the frequently measured excessive level of soil salinity in highly chemically fertilized soil (Nardi et al., 2002, Sas Paszt et al., 2011, Bardi and Malusà, 2012). Finally, our results pointed out that the response of the two plant species to same type of fertilizer applied was different, an observation which is hardly found in publications on this topic.

\section{CONCLUSIONS}

1 Fertilization of apple and sour cherry rootstock plants with organic fertilizers and amendments 
of different origin and composition is effective in producing high quality plants.

2 The application of organic fertilizers allows to reduce the amount of mineral nutrients applied, without decreasing the growth of the rootstocks.

3 The nutritional potential of these products is at least comparable, but frequently higher, than that of mineral fertilizers.

4 Products such as Tytanit, Vinassa, BF Quality, Micosat, and Humus UP showed a more significant and consistent effect on the growth of both kinds of rootstocks under different soil and climatic conditions.

Acknowledgements: The work has been supported by a grant from the EU Regional Development Fund through the Polish Innovation Economy Operational Program, contract N. UDA-POIG.01.03.01-10-109/08-00.

\section{REFERENCES}

Bardi L., Malusà E. 2012. Drought and nutritional stresses in plant: alleviating role of rhizospheric microorganisms. In: Haryana N. and Punj S. (eds.), Abiotic Stress: New Research,. Nova Science Publishers, Inc. Hauppauge, NY, USA, pp. 1-57.

Ciesielska J., Malusà E., Sas Paszt L. 2011. Nawozy i środki poprawiające właściwości gleby stosowane w rolnictwie ekologicznym. Komentarz według Załącznika I rozporządzenia Komisji (WE) nr 889/2008 ustanawiającego szczegółowe zasady wdrażania rozporządzenia Rady
(WE) $\mathrm{nr} 834 / 2007 \mathrm{w}$ sprawie produkcji ekologicznej i znakowania produktów ekologicznych w odniesieniu do produkcji ekologicznej, znakowania i kontroli. Instytut Ogrodnictwa, Skierniewice, Poland. pp 3-34.

Comerford N.B. 2005. Soil factors affecting nutrient bioavailability. In Bassiri Rad H. (ed.), Nutrient acquisition by plants: An ecological perspective, Springer-Verlag, Berlin Heidelberg 181: 1-14.

Grzyb Z.S., Bielicki P., Piotrowski W., Sas Paszt L., Malusà E. 2012. Effect of some organic fertilizers and amendments on the quality of maidens trees of two apple cultivars. Proc. $15^{\text {th }}$ Intern. Confer. on Organic Fruit Growing. $20^{\text {th }}-22^{\text {th }}$ February 2012. Univ. of Hoheinheim Germany, pp. 410-414.

Gudarowska E., Szewczuk A. 2004. Jakość materiału szkółkarskiego i plonowanie młodych drzew dwóch odmian jabłoni w zależności od podkładki i jej średnicy. FOL. UNIV. AGRICULT. STETIN. AGRICULT. 96 (240).

Janisz A., Lipecki J., Magierski J., Szwedo J. 2000. Dokarmianie jabłoni w szkółkach. SZKÓŁKARSTWO 2: 18-19.

Khan W., Rayirath U.P., Subramanian S., Jithesh M.N., Rayorath P., Hodges D.M., Critchley A.T., Craigie J.S., Norrie J., Prithiviraj B. 2009. Seaweed Extracts as Biostimulants of Plant Growth and Development. J PLANT GROWTH REGUL. DOI 10.1007/s00344-0099103-x, 28: 386-399.

Kłosowski W., Czynczyk A. 1974. Poziom nawożenia szkółek jabłoni w Polsce. PR. INST. SAD., 18: 73-89.

Malusà E., Laurenti E., Ghibaudi E., Rolle L. 2004. Influence of organic and conventional management on yield and 
composition of grape cv. Grignolino. ACTA HORT. 640: 135-141.

Malusà E., Sas Paszt L., Popińska W., Żurawicz E. 2007. The effect of a substrate containing arbuscular mycorrhizal fungi and rhizosphere microorganisms (Trichoderma, Bacillus, Pseudomonas and Streptomyces) and foliar fertilization on growth response and rhizosphere $\mathrm{pH}$ of three strawberry cultivars. INT. J. FRUIT SCI. 6(4): 25-41.

Marchers H. 1995. The Mineral Nutrition of Higher Plants, $2^{\text {nd }}$ edition, Academic Press, London, U.K, pp 3-210.

Nardi S., Pizzeghello D., Muscolo A., Vianello A. 2002. Physiological effects of humic substances on higher plants. SOIL BIOL. \& BIOCHEM., 34: 1527-1536.

Piccolo A., Nardi S., Concheri G. 1992. Structural characteristics of humus and biological activity. SOIL BIOL. BIOCHEM. 24: 273-380.

Rejman A., Makosz E. 1994. Szkółkarstwo roślin sadowniczych. PLANTPRESS, Kraków, pp 3-270.

Sas Paszt L., Sumorek B., Malusà E., Głuszek S., Derkowska E. 2011. The influence of bioproducts on root growth and mycorrhizal occurrence in the rhizosphere of strawberry plants 'Elsanta'. J. FRUIT ORNAM. PLANT RES. 19(1): 13-34.

Słowiński A. 2001. Podkładka a wzrost okulantów jabłoni w szkółce. SZKÓŁKARSTWO 2: 13-16.

Słowiński A., Sadowski A. 2000. Wzrost i rozgałęzianie okulantów jabłoni 'Elise' w szkółce w zależności od podkładki. ZESZ. NAUK. INST. SADOW. I KWIAC., 8: 67-71.

Smoleń S. 2008. Preparaty polepszające właściwości podłoża. HASŁO OGROD. 9: 15-19.

Van Trump J.I., Sun Y., Coates J.D. 2006. Microbial interactions with humic substances. ADVANCES APPL. MICROBIOL., 60: 55-96.

Wójcik P. 2000. Tytan - Korzystny składnik dla jabłoni. OWK 23: 9.

Wójcik P. 2005. Nawożenie pozakorzeniowe w uprawie roślin sadowniczych. Modernizacja sadownictwa w dostosowaniu do wymogów Unii Europejskiej. X Ogólnopolskie Spotkanie Sadowników w Grójcu. Grójec, 1920 stycznia 2005: 85-92.

Wójcik P. 2009. Nawozy i nawożenie drzew owocowych. HORTPRESS, Warszawa, pp 7-257. 


\title{
WPŁYW RÓŻNYCH NAWOZÓW I ULEPSZACZY ORGANICZNYCH NA WZROST PODKŁADEK JABŁONI I WIŚNI STOSOWANYCH W PIERWSZYM ROKU PROWADZENIA SZKÓŁKI EKOLOGICZNEJ
}

\author{
Zygmunt S. Grzyb, Wojciech Piotrowski, Paweł Bielicki, \\ Lidia Sas Paszt i Eligio Malusà
}

S T R E S Z C Z E N I E

Doświadczenia z podkładkami jabłoni M.26 i wiśni - siewek antypki (Prunus mahaleb L.) prowadzono w latach 2009-2010 w trzech różnych miejscowościach. Oceniano wpływ siedmiu różnych nawozów organicznych na ich wzrost w pierwszym roku prowadzenia szkółki ekologicznej. Testowane były produkty: mieszanina pożytecznych mikroorganizmów glebowych (Micosat), ekstrakt z wermikompostu (Humus UP), ekstrakt kwasów huminowych (Humus Active i Aktywit PM), dwa rodzaje ekstraktów z roślin i wodorostów (BioFeed Amin, BioFeed Quality), wywar gorzelniczy z produkcji drożdży (Vinassa) i roztwór tytanitu (Tytanit). Rośliny traktowane tymi produktami były porównywane z roślinami niczym nie traktowanymi lub traktowanymi organicznym obornikiem oraz nawozami mineralnymi. Wzrost roślin oceniano mierząc średnicę szyjki korzeniowej i wysokość najwyższego pędu. Badania wykazały, że stosowanie różnych biopreparatów w stosunku do kombinacji kontrolnej i większości kombinacji nawożonych mineralnie i obornikiem spowodowało poprawę wzrostu obu rodzajów podkładek we wszystkich szkółkach zlokalizowanych w różnych miejscowościach, w każdym roku badań. Większość produktów (BioFeed Quality, Micosat, Tytanit i Vinassa) niezależnie od lokalizacji, rodzaju gleby i warunków klimatycznych poprawiały jakość traktowanych podkładek. Rosły one wyraźnie lepiej niż nawożone innymi nieorganicznymi produktami.

Słowa kluczowe: podkładki jabłoni M.26, siewki antypki (Prunus mahaleb L.), aplikacja bioproduktów, szkółka ekologiczna 